\title{
PERSEPSI KEPALA SEKOLAH DAN GURU TENTANG MUTU SEKOLAH
}

( Studi Kasus di SMP Negeri 4 Sambas)

\section{Oleh: Faisal ${ }^{1}$}

\begin{abstract}
Abstrak: Kelebihan yang dimiliki SMPN 4 Sambas belum mampu mengantarkannya menjadi sekolah bermutu di Kabupaten Sambas. Metode yang digunakan adalah pendekatan penelitian kualitatif, jenis penelitian studi kasus, orientasi teoritisnya mengacu pada teori Fenomenologi. Hasil wawancara, pengamatan dan dokumen sekolah terungkap bahwa; 1) Profil sekolah memenuhi SNP, (2) Kepala sekolah dan guru memberikan persepsi yang sama tentang mutu sekolah.
\end{abstract}

Kata Kunci: persepsi, kepala sekolah, guru, mutu sekolah

\section{Pendahuluan}

Isu penting yang sering dikaitkan dengan dunia pendidikan di Indonesia saat ini adalah lemahnya daya saing bangsa dan rendahnya kualitas sumber daya manusia (Idrus, 2009.124)

Hadis dan Nurhayati (2010.2-3) mengatakan bahwa dalam perspektif mikro faktor dominan yang berpengaruh dan berkontribusi besar terhadap mutu pendidikan ialah guru yang profesioanal dan guru yang sejahtera.

Mulyasa ( 2009.5) mengatakan bahwa guru merupakan komponen yang paling berpengaruh terhadap terciptanya proses dan hasil pendidikan yang berkualitas.

Hal ini berarti kehadiran guru dalam proses pembelajaran di sekolah masih tetap memegang peranan yang penting. Peran tersebut belum dapat diganti dan diambil alih oleh apapun. Ada unsur-unsur manusiawi dalam proses belajar mengajar yang tidak dapat diganti oleh unsur lain. Ada etika dan nilai yang secara kodrati melekat pada manusia yang membuat pendidikan itu mengandung nilai seni yang tidak dimiliki oleh selain manusia.

Seperti yang dikatakan oleh Mulyasa (2009.5) bahwa guru merupakan komponen yang paling menentukan untuk meningkatkan kualitas pendidikan. Karena ditangan gurulah kurikulum, sumber belajar, sarana dan prasarana, dan iklim pembelajaran menjadi berarti bagi kehidupan peserta didik.

${ }^{1}$ Fasisal : Kepala SMP Negeri 9 Teluk Keramat Sambas 
Kenyataannya, harapan setelah lulus dapat melanjutkan ke sekolah yang dituju kandas lantaran kualitas yang mereka miliki tidak memenuhi syarat yang ditentukan oleh sekolah yang dituju. Artinya sekolah tempat anak tersebut mempersiapkan diri untuk ke sekolah berikutnya tidak mampu mempersiapkan anak tersebut untuk memasuki sekolah yang dituju. Oleh karena itu perlu pengelolaan yang serius terhadap institusi tersebut agar dapat menghasilkan lulusan yang berkualitas. Sekolah yang menghasilkan lulusan yang berkualitas dianggap sebagai sekolah yang memiliki produktivitas baik, demikian sebaliknya.

Widodo (2011.12) mengatakan bahwa mutu lulusan tidak dapat dipisahkan dari suatu alur siklus mulai contect, Input, Proses,Output, dan Outcome. Untuk itu kata Widodo mutu lulusan yang sesuai dengan keinginan pelanggan pendidikan adalah output yang mempunyai kriteria sebagai out comes yaitu dapat melanjutkan ke sekolah yang lebih tinggi dan dapat mempersiapkan diri peserta didik untuk melanjutkan sekolah ditingkat yang lebih tinggi dan dapat bekerja.

Mulyono (2008.308) mendifinisikan mutu sebagai kemampuan untuk memenuhi persyaratan-persyaratan. Jenkins dalam (Widodo (2011.13) mengatakan, "Sekolah yang memiliki kriteria baik adalah sekolah yang mampu menghasilkan sedikit lulusan yang tidak siap pakai, sedikit yang tidak lulus, dan banyak lulusan melanjutkan pendidikan ke jenjang terpilih yang lebih tinggi."

Permasalah pendidikan di atas tidak jauh berbeda dengan apa yang terjadi di SMP Negeri 4 Sambas. Berdasarkan data, tahun pelajaran 2011/2012 sekolah yang dipimpin oleh Urai Riza Fahmi, S. Pd ini memilik personil 38 orang terdiri dari 22 orang guru tetap PNS (11 laki dan 11 perempun) termasuk kepala sekolah dan 6 orang (1 laki dan 5 perempuan) guru non PNS (honorer). Dari 22 guru PNS tersebut 12 orang guru telah memiliki sertifikat pendidik, 5 orang baru saja selesai mengikuti PLPG kuota 2011. Tenaga administrasi tetap PNS 3 orang, Tenaga administrasi non PNS (honorer) 3 orang, penjaga sekolah non PNS (honorer) 2 orang dan petugas kebersihan non PNS (honorer) 2 orang. Jumlah siswanya 336 orang terdiri 142 orang laki-laki dan 194 orang perempuan terbagi dalam 14 rombongan belajar.

Sekolah yang didirikan tahun 1984 ini dalam perkembangannya memiliki beberapa kelebihan antara lain; ketika program sertifikasi guru dalam jabatan pada tahun 2007 digulirkan, SMP Negeri 4 Sambas memiliki guru bersertifikat pendidik paling banyak bila dibandingkan dengan SMP Negeri yang lain di kecamatan Sambas. 
Tahun 2004 ditetapkan sebagai piloting dan tahun 2006 ditetapkan sebagai piloting KTSP sehingga $91 \%$ dari 22 guru pernah mengikuti penataran tingkat nasional, prestasi non akademik yaitu olah raga pencak silat sampai tingkat provinsi dan untuk tingkat Kabupaten Sambas olahraga sepak bola dan voly sangat disegani lawan, sarana prasarana pembelajaran memadai, lokasi sekolah strategis, lingkungan belajar kondusif, halaman dan taman luas.

Melihat beberapa kelebihan yang dimiliki dan jika salah satu ukuran mutu sekolah adalah nilai Ujian Nasional, maka sekolah ini diharapkan setiap tahun banyak siswanya lulus dengan nilai di atas rata-rata sekolah lain sehingga sekolah masuk dalam deretan minimal sepuluh besar Rayon Kabupaten Sambas, atau sedikit yang tidak lulus dan lulusan tidak ragu untuk bersaing atau banyak lulusan yang masuk sekolah favorit, sebagai mana dikatakan oleh Jenkins dalam (Widodo (2011.13) bahwa sekolah yang memiliki kriteria baik adalah sekolah yang mampu menghasilkan sedikit lulusan yang tidak siap pakai, sedikit yang tidak lulusan, dan banyak lulusan melanjutkan pendidikan ke jenjang sekolah terpilih yang lebih tinggi.

Kenyataannya adalah SMP Negeri 4 Sambas bertolak belakang dari harapan di atas dan untuk menyiasati kondisi tersebut peneliti berasumsi bahwa kepala sekolah dan guru SMP Negeri 4 Sambas sebaiknya tidak mengabaikan persepsi mereka terhadap mutu sekolah.

Asumsi di atas menarik peneliti untuk mengungkap kasus persepsi kepala sekolah dan guru terhadap mutu sekolah yang diyakini dapat bermanfaat bagi perkembangan mutu sekolah tersebut khususnya dan pendidikan umumnya.

\section{Fokus Penelitian}

Untuk menjawab pertanyaan penelitian, "Bagaimanakah persepsi kepala sekolah dan guru SMP Negeri 4 Sambas tentang mutu sekolah?", maka fokus penelitian diarahkan pada:

1. Bagaimana profil SMP Negeri 4 Sambas?

2. Bagaimana persepsi kepala sekolah tentang mutu sekolah?

3. Bagaimana persepsi guru tentang mutu sekolah?

\section{Tujuan Penelitian}

Tujuan utama dari penelitian ini adalah untuk mendeskripsikan persepsi kepala sekolah dan guru terhadap mutu sekolah di SMP Negeri 4 Sambas. 


\section{Metodologi Penelitian}

Dilihat dari latar belakang alamiah dan peneliti merupakan instrumen utama meletakkan penelitian ini sebagai penelitian kualitatif dan jenis penelitian studi kasus. Pendekatan eksploratif yang bersifat mendalam dengan menganalisis apa yang sebenarnya terjadi di balik fakta atau kasus. "Peneliti tidak akan memandang bahwa sesuatu itu sudah memang sedemikian keadaannya (Moleong 2011.11)

Dengan demikian orientasi teoritisnya mengacu pada teori Fenomenologi, sebagaimana dikatakan oleh Moleong (2011.14) bahwa "pada dasarnya landasan teoritis dari penelitian kualitatif bertumpu secara mendasar pada fenomenologi". Fenomenologi pada dasarnya berpandangan bahwa apa yang tampak dipermukaan, termasuk pola perilaku manusia sehari-hari hanyalah sesuatu gejala atau fenomena dari apa yang tersembunyi di "kepala" sang pelaku. Realitas itu sesungguhnya bersifat subyektif dan maknawi. Ia bergantung pada persepsi, pemahaman, pengertian, dan anggapan-anggapan seseorang ( Bungin. (Ed). 2008.9).

\section{Landasan Konseptual \\ Propil Sekolah}

Profil diartikan sebagai wajah atau bentuk sesuatu yang memiliki ciriciri khusus. Ciri-ciri khusus yang dimiliki oleh sesuatu itulah (misalkan sekolah) yang membedakan (sekolah) yang satu dengan (sekolah) yang lain.

Profil sekolah adalah wajah, gambaran dan informasi tentang suatu sekolah dengan segala muatan yang dimilikinya. Berbicara propil suatu sekolah berarti kita ingin mengetahui tentang sekolah tersebut yaitu tentang sejarahnya, letaknya, sarana prasarananya, personil, siswa, program yang telah dan akan dicapai, serta visi, misi dan tujuan yang hendak di capai oleh sekolah tersebut.

\section{Persepsi}

Menurut Stephen P. Robbins (2008.175) bahwa persepsi adalah proses di mana individu mengatur dan meng-interprestasikan kesan-kesan sensoris mereka guna memberikan arti bagi lingkungan mereka. Namun, apa yang diterima seseorang pada dasarnya berbeda dari realitas objektif. Selanjutnya Stephen P. Robbins mengatakan ada 3 (tiga) faktor yang mempengaruhi persepsi, yaitu: Pelaku persepsi, Target dan Situasi

Stephen P. Robbins (2008.177) mengatakan bahwa persepsi dan penilaian kita tentang tindakan seseorang akan dipengaruhi secara siqnifikan oleh asumsi-asumsi yang kita buat tentang keadaan internal orang itu. 
Ada beberapa teknik dalam menilai orang yang memungkinkan kita membuat persepsi yang lebih akurat dengan cepat dan memberikan data yang valid (sahih) untuk membuat ramalan. Namun teknik-teknik ini akan menceburkan kita dalam kesulitan karena tidak 'foolproof'. Karena itu, pemahaman akan jalan pintas ini dapat membantu kita mewaspadai bila teknik-teknik ini menghasilkan distorsi. Teknik tersebut yaitu: Persepsi selektif, Efek halo, Efek kontras, Proyeksi, Berstereotipe (Stephen P. Robbins:2008.180-183)

Persepsi dapat dimaknai sebagai penilaian seseorang terhadap suatu per-masalahan dan penilaian tersebut sangat dipengaruhi oleh wawasan yang dimiliki seseorang terhadap permasalahan tersebut dan berpengaruh pula terhadap sikap orang tersebut terhadap permasalahan yang dinilai.

\section{Mutu}

Terkait dengan mutu Bill Creech (1996.6) mengatakan bahwa produk adalah titik fokus untuk tujuan dan pencapaian organisasi. Mutu dalam produk tidak mungkin dicapai tanpa mutu dalam proses. Mutu dalam proses tidak mungkin dicapai tanpa organisasi yang tepat. Organisasi yang tepat tidak ada artinya tanpa kepemimpinan yang memadai. Komitmen yang kuat, dari bawah ke atas merupakan dukungan pilar untuk pilar yang lain. Setiap pilar tergantung pada empat pilar yang lain, dan bila ada salah satu yang lemah semuanya akan lemah. Jadi lima pilar yang saling terkait tersebut adalah produk, proses, organisasi, kepemimpinan, dan Komitmen.

Kosasih (2010.16) mengatakan bahwa dalam konteks pendidikan pengertian mutu mengacu pada proses pendidikan dan hasil pendidikan. a) Proses pendidikan yang bermutu melibatkan berbagai aspek, seperti manajemen, sekolah, dukungan administrasi, bahan ajar, sarana dan prasarana, serta penciptaan suasana yang kondusif; b) Hasil pendidikan yang bermutu yang bersifat tangible adalah prestasi sekolah yang berupa student achievement (tes kemampuan akademis) atau prestasi siswa pada bidang tertentu. Adapaun prestasi sekolah yang bersifat intangible meliputi suasana disiplin, keakraban, kebersihan, dan lain-lain.

Selanjutnya Juran dalam Hadis dan Nurhayati (2010.84) mengatakan bahwa mutu produk ialah kecocokan penggunaan produk (fitness for use) untuk memenuhi kebutuhan dan kepuasan pelanggan. Kecocokan penggunaan produk tersebut didasarkan atas lima ciri utama, yaitu (1) teknologi, yaitu kekusaan; (2) psikologi, yaitu citra rasa atau status; (3) waktu, yaitu kehandalan; (4) kontraktual, yaitu ada jaminan; (5) etika, yaitu sopan santun. 
Mulyono (2008.308) mendifinisikan mutu sebagai kemampuan untuk memenuhi persyaratan-persyaratan.

Sallis (2010.7) berpendapat bahwa se-cara operasional mutu ditentukan oleh dua factor, yaitu terpenuhinya spesifikasi yang telah ditentukan sebelumnya (quality in fact) dan terpenuhinya spesifikasi yang diharapkan menurut tuntutan dan kebutuhan pengguna jasa (quality in perception).

Dengan demikian berbicara mutu berarti terkait dengan kepuasan orang-orang yang terlibat dan memerlukan hal tersebut. Pelanggan dan pelaku yang terlibat sama-sama senang.

\section{Mutu Sekolah}

Kosasih (2010.16) mengatkan bahwa sekolah yang bermutu adalah sekolah yang keadaan atau kondisinya memiliki sifat-sifat yang sesuai tuntutan ideal dan harapan kepala sekolah, guru, karyawan, siswa, orang tua, penyandang dana, dan pemakai lulusan sekolah. Agar tuntutan ideal dan harapan tersebut dapat direalisasikan maka ada beberapa persyaratan yang harus dipenuhi oleh sekolah untuk menuju arah tersebut, sebagaimana dikatakan oleh Sukmadinata dkk (2010.9-11) bahwa ada beberapa prinsip yang perlu dipegang dalam menerapkan mutu pendidikan diantaranya adalah:

a. Peningkatan mutu pendidikan menuntut kepemimpinan profesional dalam bidang pendidikan.

b. Kesulitan yang dihadapi oleh para profesional kepemimpinan adalah ketidakmampuan mereka dalam meng-hadapi "kegagalan sistem" yang men-cegah mereka dari pengembangan atau penerapan cara atau proses baru untuk memperbaiki mutu pendidikan yang ada.

c. Peningkatan mutu pendidikan harus melakukan loncatan-loncatan yang mampu bersaing di dunia global.

d. Uang bukan kunci utama dalam usaha peningkatan mutu.

e. Kunci utama dalam peningkatan mutu adalah komitmen pada perubahan.

f. Banyak profesional di bidang pendi-dikan yang kurang memiliki pengetahuan dan keahlian dalam menyiapkan para siswa memasuki pasar kerja yang bersifat global. Ketakutan terhadap perubahan, atau takut melakukan perubahan akan meng-akibatkan ketidaktahuan bagai mana mengatasi tuntutan-tuntutan baru.

g. Program peningkatan mutu dalam bidang komersial tidak dapat dipakai secara langsung dalam bidang pendidikan, tetapi membutuhkan penyesuaian dan penyempurnaan.

h. Salah satu komponen kunci dalam program mutu adalah sistem pengukuran. 
i. Masyarakat dan manajemen pendidikan harus menjauhkan diri dari kebiasaan menggunakan "program singkat", sebab peningkatan mutu dapat dicapai melalui perubahan yang berkelanjutan tidak dengan program- program singkat.

Widodo (2011.12) mengatakan bahwa mutu lulusan tidak dapat dipisahkan dari suatu alur siklus mulai contect, Input, Proses, Output, dan Outcome. Untuk itu kata Widodo mutu lulusan yang sesuai dengan keinginan pelanggan pendidikan adalah output yang mempunyai kriteria sebagai out comes yaitu dapat melanjutkan ke sekolah yang lebih tinggi dan dapat mempersiapkan diri peserta didik untuk melanjutkan sekolah ditingkat yang lebih tinggi dan dapat bekerja.

Satu hal yang bisa kita yakini adalah mutu merupakan suatu hal yang membedakan antara yang baik dan yang sebaliknya..., mutu dalam pendidikan akhirnya merupakan hal yang membedakan antara kesuksesan dan kegagalan (Sallis: 2010.30).

\section{Pembahasan Temuan Penelitian}

\section{Profil SMP Negeri 4 Sambas}

Dilihat dari kepemilikan sarana dan prasarana, SMP Negeri 4 Sambas tidak mendapat kesulitan dalam melaksanakan proses belajar mengajar sebagaimana dokumen Profil Mutu Satuan Pendidikan hasil laporan Evaluasi Diri Sekolah SMP Negeri 4 Sambas tahun 2011 yang mengatakan bahwa 8 (delapan) standar pendidikan menunjukkan kinerjanya telah mencapai tahap 4 yang berarti sudah berada di atas SNP, kecuali Standar Pembiayaan kinerjanya mencapai tahap 2 yang berarti sudah memenuhi SPM namun belum memenuhi SNP.

Pernah menjadi piloting KBK tahun 2004 dan KTSP tahun 2006. Terkait hal tersebut $91 \%$ dari 22 guru pernah mengikuti penataran tingkat nasional. Selama periode tersebut sering kali pertemuan MGMP atau kegiatan pengembangan kurikulum selalu melibatkan guru-guru SMP Negeri 4 Sambas sebagai fasilitator atau model. Akibatnya kelas yang menjadi tanggung jawabnya terabaikan karena guru-guru tersebut ditugaskan sebagai fasilitator atau model di sekolah lain.

Sebagai sekolah piloting KBK dan KTSP sehingga 96 persen dari 22 guru yang ada saat itu ikut latihan dan penataran tingkat nasional berarti kondisi tersebut merupakan kelebihan yang ada pada SMP Negeri 4 Sambas. Jika kelebihan tersebut dapat dimanfaatkan oleh guru-guru yang ada untuk mengembangkan diri terutama kompetensi pedagogis dan profesionalnya, dapat dikelola oleh manajemen sekolah dengan baik, tidak menutup 
kemungkinan akan berpengaruh pada mutu kinerja. Dan akhirnya akan berpengaruh pada kualitas sekolah. Hal ini sesuai dengan tawaran Hackman dan Oldham, bahwa pelatihan merupakan pilihan untuk memgubah masyarakat dikaitkan dengan pekerjaan apa yang sedang mereka lakukan ( Nadler dalam Sinju 2000:213).

Kenyataannya, justru sebagai piloting KBK dan KTSP kondisi sekolah terabaikan karena implementasi kompetensi yang dimiliki guru-guru SMP Negeri 4 Sambas dari pelatihan tingkat nasional tersebut lebih banyak dipergunakan untuk kegiatan MGMP, fasilitator atau model yang dilaksanakan oleh sekolah lain. Guru-guru SMP Negeri 4 Sambas pada waktu itu ibarat 'lilin'. Kebijakan menghendaki mereka harus berbagi hasil pelatihan yang mereka peroleh ditingkat nasional ke sekolah-sekolah lain, sementara sekolah tempat mereka mengajar terabaikan dan secara perlahan mutu sekolah menurun karena guru-gurunya sedang konsentrasi sebagai fasilitator dalam kegiatan MGMP atau IHT yang dilakukan oleh sekolah lain.

Dampaknya mutu sekolah menurun, hasil ujian nasional merosot. Ketika ada seleksi penetapan sekolah Sekolah Standar Nasional di wilayah kerja Dinas Pendidikan Kabupaten Sambas, sekolah ini kalah saing dengan SMP Negeri 2 Sambas. Ini berarti peluang dan kelebihan yang ada pada SMP Negeri 4 Sambas tidak dapat dimanfaatkan dengan baik, sebagaimana yang dituturkan oleh Uray Reza Fahmi,S.Pd. ( kepala sekolah saat ini) sbb;

"Saya tidak tahu persis apakah terpilihnya SMP Negeri 4 Sambas sebagai piloting KBK dan KTSP di wilayah kerja Dinas Pendidikan Kabupaten Sambas karena faktor kedekatan Kepala Sekolah (saat itu) dengan penentu kebijakan di Dinas Pendidikan Kabupaten atau memamg SMP Negeri 4 Sambas memiliki syarat untuk itu. Tapi yang pasti ketika akan diadakan pemilihan Sekolah Standar Nasional (SSN), sekolah ini tidak terpilih sebagai Sekolah Standar Nasional (SSN) di Kabupaten Sambas, yang terpilih justru SMP Negeri 2 Sambas".

Hasil ujian nasional tahun pelajaran 2009/2010 rendah, maka tahun pelajaran 2010/2011 SMP Negeri 4 Sambas termasuk salah satu sekolah yang mendapat bantuan dana Rp. 50.000.000,- dari Dirjen Peningkatan Mutu Kementerian Pendidikan Nasional dalam rangka program peningkatan hasil ujian.

Sesuai dengan sasarannya, pengucuran dana dari Dirjen Peningkatan Mutu Kementerian Pendidikan Nasional adalah dalam rangka program peningkatan kelulusan ujian yang diperuntukkan bagi sekolah yang kelulusan ujian nasionalnya tahun pelajaran 2009/2010 menurut Dirjen Peningkatan Mutu Kementerian Pendidikan Nasional rendah. Penetapan sekolah dengan 
kelulusan rendah tersebut berdasarkan pemetaan hasil ujian nasional dari Dinas Pendidikan Kabupaten.

Dengan adanya bantuan dana tersebut hasil kelulusan SMP Negeri 4 Sambas tahun pelajaran 2010/2011 meningkat. Seiring dengan meningkatnya hasil ujian di SMP Negeri 4 Sambas, pada tahun pelajaran 2010/2011 juga berubah sistem perhitungan penilaian kelulusan. Berdasarkan Lampiran Peraturan Badan Standar Nasional Pendidikan Nomor: 0011/P/BSNP/XII/2011 tentang POS UN 2011, bagian VII dinyatakan bahwa Nilai Sekolah diperoleh dari gabungan antara nilai Ujian Sekolah dan nilai rata-rata rapor semester 1, 2, 3, 4, dan 5 untuk SMP/MTs dengan pembobotan $60 \%$ untuk nilai Ujian Sekolah dan $40 \%$ untuk nilai rata-rata rapor. Tahun pelajaran 2009/2010 sistem penilaian kelulusan nilai sekolah tidak diperhitungkan.

Kalau begitu mesti perlu ditanyakan perubahan kenaikan kelulusan tahun pelajaran 2010/2011 tersebut terkait dengan kinerja guru, atau perubahan sistem penilaian kelulusan.

\section{Persepsi Kepala Sekolah tentang Mutu Sekolah}

Dengan kualifikasi pendidikan dan kompetensi yang sudah memenuhi standar nasional pendidikan yang dimilikinya, ditemukan dari ungkapan kepala sekolah mengenai persepsinya tentang mutu sekolah adalah kemampuan sekolah untuk meluluskan seluruh siswanya sesuai dengan standar yang telah ditentukan oleh pemerintah, lulusan dapat bersaing dengan lulusan sekolah lain yang sederajat untuk melanjutkan pendidikan ke sekolah selanjutnya.

Faktor-faktor yang mempengaruhi mutu sekolah menurut penututran beliau antara lain; a) kualitas dan aktivitas guru, b) sarana prasarana, c) input siswa, dan d) kondisi lingkungan. Di SMP Negeri 4 Sambas faktor-faktor tersebut belum dikelola dengan baik sehingga mutu sekolah rendah.

Langkah-langkah yang ditempuh untuk meningkatkan mutu sekolah di SMP Negeri 4 Sambas kepala sekolah melaksanakan manajemen partisipatif.

Temuan di atas sesuai dengan pendapat Jenkins dalam (Widodo: 2011.13) mengatakan "Sekolah yang memiliki kriteria baik adalah sekolah yang mampu menghasilkan sedikit lulusan yang tidak siap pakai, sedikit yang tidak lulus, dan banyak lulusan melanjutkan pendidikan ke jenjang terpilih yang lebih tinggi."

Berkenaan dengan mutu sekolah khususnya Mutu SMP Negeri 4 Sambas sebagaimana maksud penelitian ini, sekolah tersebut belum mampu merialisasikan konsep mutu sekolah sebagaimana diutarakan oleh kepala 
sekolah. Padahal sekolah ini memiliki kekuatan yaitu memiliki kinerja pemenuhan 8 SNP sebagian besar telah memenuhi SNP kecuali Standar Pembiaya-an yang baru memenuhi SPM sebagaimana penuturan kepala sekolah berikut ini: "Kalau ukuran mutu suatu sekolah adalah banyak tidaknya siswa yang lulus Ujian Nasional, maka mutu SMP Negeri 4 Sambas masih jauh dari harapan. Harapannya SMP Negeri 4 Sambas lulus 100 persen setiap tahun, tapi kenyataannya perlu usaha dan kerja sama semua warga sekolah kearah tersebut.

Di SMP Negeri 4 Sambas faktor-faktor tersebut belum dikelola dengan baik sehingga mutu sekolah rendah. Langkah yang ditempuh oleh kepala sekolah untuk meningkatkan mutu sekolah di SMP Negeri 4 Sambas dengan melaksanakan manajemen partisipatif. Agar program tersebut efektif harus didukung oleh guru, pegawai, orangtua, komite sekolah dan stokeholder lainnya dan disesuaikan dengan kondisi riil di SMP Negeri 4 Sambas.

Jika data yang diberikan oleh pihak SMP Negeri 4 Sambas dalam mengisi EDS online 2011 itu valid maka quality in fact ( Mutu sesungguhnya) dan quality in perception ( Mutu menurut persepsi ) akan terpenuhi sebagai mana menurut Sallis (2010.7) yang mengatakan bahwa dalam penyelengaraannya quality in fact merupakan profil lulusan institusi pendidikan yang sesuai dengan kualifikasi tujuan pendidikan, yang berbentuk standar kemampuan dasar berupa kualifikasi akademik minimal yang dikuasai oleh peserta didik sedangkan quality in perception pendidikan adalah kepuasan dan bertambah-nya minat pelanggan eksternal terhadap lulusan institusi pendidikan.

Beranjak dari Faktor-faktor tersebut oleh kepala sekolah dirasakan masih kurang optimal dalam operasinya, ada baiknya pendapat Sallis (2010.7-10) dijadikan bahan pertimbangan yaitu; pertama perbaikan secara terus menerus (countinuous improvement), kedua menentukan standar mutu (quality assurance), ketiga perubahan kultur (change of cultur), keempat perubahan organisasi (upside-down organization), dan kelima mempertahankan hubungan dengan pelanggan (keeping close to the customer).

Terkait dengan faktor yang mempengaruhi mutu sekolah, Widodo (2011.12) mengatakan bahwa mutu lulusan tidak dapat dipisahkan dari suatu alur siklus mulai contect, Input, Proses, Output, dan Outcome. Untuk itu kata Widodo mutu lulusan yang sesuai dengan keinginan pelanggan pendidikan adalah output yang mempunyai kriteria sebagai out comes yaitu dapat melanjutkan ke sekolah yang lebih tinggi dan dapat mempersiapkan diri 
peserta didik untuk melanjutkan sekolah ditingkat yang lebih tinggi dan dapat bekerja.

\section{Persepsi Guru tentang Mutu Sekolah}

Ditemukan ada kemiripan diantara guru-guru dalam mengungkapkan persepsi mutu sekolah yaitu bentuk pelayanan yang diberikan sekolah kepada siswa dengan ketentuan pelayanan yang diberikan dapat menjadikan anak didiknya memiliki akhlak mulia, mengamalkan ajaran agamanya dengan baik, hormat dengan guru, mematuhi peraturan yang dibuat sekolah, tingkah lakunya di sekolah maupun di masyarakat sesuai norma yang berlaku, dan hasil pelayanan yang diberikan dapat melewati standar minimal yang ditentukan oleh regulasi yang berlaku sehingga lulusan dapat melanjutkan sekolah kejenjang berikutnya. Pelayanan yang diberikan merupakan akomodasi dari semua pemikiran guru dan pegawai menjadi suatu kebijakan yang dilaksanakan oleh sekolah.

Guru yang ada di SMP Negeri 4 Sambas memiliki kelayakan secara akademis untuk melaksanakan proses pembelajaran. Tuntutan perkembangan zaman menghendaki seorang guru harus profesional. Untuk men-jadi profesional guru disyaratkan memenuhi kualitas akademik minimum (guru SMP minimal S1) dan dan bersertifikat pendidik. Guru-guru yang memenuhi kriteria profesional inilah diharapkan yang akan mampu menjalankan pendidikan dan pembelajaran untuk mencapai tujuan pendidikan nasional, yakni berkembangnya potensi peserta didik agar menjadi manusia yang beriman dan bertakwa, berkhlak mulia, sehat, berilmu, cakap, kreatif, mandiri, serta menjadi warga negara yang demokratis dan bertanggung jawab.

Sumber daya manusia yang berkualitas ini bila dikelola dengan baik merupakan kekuatan yang dapat dimanfaatkan untuk mencapai visi, misi serta tujuan yang telah direncanakan pihak sekolah. Semua itu sangat tergantung pada kehadiran guru di kelas. Karena sebagian besar hasil pendidikan yang baik dimulai dari keberadaan guru di kelas.

Kehadiran guru dalam proses pembelajaran di sekolah masih tetap memegang peranan yang penting. Peran tersebut belum dapat diganti dan diambil alih oleh apapun. Ada unsur-unsur manusiawi dalam proses belajar mengajar yang tidak dapat diganti oleh unsur lain. Ada etika dan nilai yang secara kodrati melekat pada manusia yang membuat pendidikan itu mengandung nilai seni yang tidak dimiliki oleh selain manusia. Guru adalah figur manusia sumber yang menempati posisi dan memegang peran penting dalam pendidikan. 
Oleh karena itu kehadiran sosok guru di dalam kelas atau dalam pelaksanaan proses pembelajaran merupakan suatu keharusan. Keberhasilan penyelenggaraan pendidikan sangat ditentukan kesiapan guru dalam mempersiapkan peserta didiknya dalam kegiatan pembelajaran. Jika guru sering terlambat masuk kelas atau sering meninggalkan kelas tentu akan berakibat kurang baik terhadap pencapaian tujuan sekolah.

Terakit hal ini Mulyasa ( 2009.5) mengatakan, "Guru merupakan komponen yang paling berpengaruh terhadap terciptanya proses dan hasil pendidikan yang berkualitas. Oleh karena itu, upaya perbaikan apapun yang dilakukan untuk meningkatkan kualitas pendidikan tidak akan memberikan sumbangan yang signifikan tanpa didukung oleh guru yang profesional dan berkualitas. Perbaikan kualitas pendidikan harus berpangkal dari guru dan berujung pada guru pula."

Berdasarkan temuan di atas, bila dikaitkan dengan hasil yang dicapai oleh sekolah dalam meluluskan siswanya berarti guru belum mampu sepenuhnya memberikan pelayanan. Hal ini dibuktikan oleh perolehan kelulusan yang masih rendah. Padahal posisi strategis guru untuk meningkatkan mutu hasil pendidikan sangat dipengaruhi oleh kompetensi dan mutu kinerjanya, dan secara umum mutu pendidikan yang baik menjadi tolok ukur bagi keberhasilan kinerja yang ditunjukkan guru.

Seperti yang dikatakan oleh Mulyasa (2009.5) bahwa guru merupakan komponen yang paling menentukan untuk meningkatkan kualitas pendidikan. Karena ditangan gurulah kurikulum, sumber belajar, sarana dan prasarana, dan iklim pembelajaran menjadi berarti bagi kehidupan peserta didik.

Senada dengan persepsi guru tentang mutu sekolah diatas, Kosasih (2010.16) mengatkan bahwa "sekolah yang bermutu adalah sekolah yang keadaan atau kondisinya memiliki sifat-sifat yang sesuai tuntutan ideal dan harapan kepala sekolah, guru, karyawan, siswa, orang tua, penyandang dana, dan pemakai lulusan sekolah". Agar tuntutan ideal dan harapan tersebut dapat direa-lisasikan maka ada beberapa persyaratan yang harus dipenuhi oleh sekolah untuk menuju arah tersebut, sebagaimana dikatakan oleh Sukmadinata dkk (2010.9-11) bahwa ada beberapa prinsip yang perlu dipegang dalam menerapkan mutu pendidikan dianta-ranya adalah:

a. Peningkatan mutu pendidikan menuntut kepemimpinan profesional dalam bidang pendidikan.

b. Kesulitan yang dihadapi oleh para profesional kepemimpinan adalah keti-dakmampuan mereka dalam menghadapi "kegagalan sistem" yang mencegah mereka dari pengembangan atau penerapan cara atau proses baru untuk memperbaiki mutu pendidikan yang ada. 
c. Peningkatan mutu pendidikan harus melakukan loncatan-loncatan yang mampu bersaing di dunia global.

d. Uang bukan kunci utama dalam usaha peningkatan mutu.

e. Kunci utama dalam peningkatan mutu adalah komitmen pada perubahan.

f. Banyak profesional di bidang pendi-dikan yang kurang memiliki pengetahuan dan keahlian dalam menyiapkan para siswa memasuki pasar kerja yang bersifat global. Ketakutan terhadap perubahan, atau takut melakukan peru-bahan akan mengakibatkan ketidak-tahuan bagaimana mengatasi tuntutan-tuntutan baru.

g. Program peningkatan mutu dalam bidang komersial tidak dapat dipakai secara langsung dalam bidang pendi-dikan, tetapi membutuhkan penyesuaian dan penyempurnaan.

h. Salah satu komponen kunci dalam program mutu adalah sistem pengukuran.

i. Masyarakat dan manajemen pendidikan harus menjauhkan diri dari kebiasaan menggunakan "program singkat", sebab peningkatan mutu dapat dicapai melalui perubahan yang berkelanjutan tidak dengan program- program singkat.

Persepsi mutu sekolah tersebut oleh Stephen P.Robins (2008.175) dikategorikan sebagai salah satu faktor yang mempengaruhi seseorang dalam memberikan persepsi yaitu faktor pelaku persepsi. Pelaku persepsi adalah penafsiran seorang individu pada suatu objek yang dilihatnya akan sangat dipengaruhi oleh karakteristik pribadinya sendiri, diantaranya sikap, motif, kepentingan atau minat, pengalaman masa lalu, dan pengharapan. Kebutuhan atau motif yang tidak dipuaskan akan merangsang individu dan mempunyai pengaruh yang kuat pada persepsi mereka.

Dengan demikian konsep mutu sekolah sebagaimana diutarakan diatas bila diimplementasikan sebagaimana dimaksudkan oleh penutur tentu akan menghasilkan pendidikan yang berkualitas. Seperti yang dikatakan oleh Mulyasa (2009.5) bahwa guru merupakan komponen yang paling menentukan untuk meningkatkan kualitas pendidikan. Karena ditangan gurulah kurikulum, sumber belajar, sarana dan prasarana, dan iklim pembelajaran menjadi berarti bagi kehidupan peserta didik.

\section{Penutup}

Dilihat dari Propfil sekolah bahwa SMP Negeri 4 Sambas tidak mendapat kesulitan dalam melaksanakan proses belajar mengajar karena 8 (delapan) standar pendidikan menunjukkan kinerjanya telah mencapai tahap 4 yang berarti sudah berada di atas SNP, kecuali Standar Pembiayaan 
kinerjanya mencapai tahap 2 yang berarti sudah memenuhi SPM namun belum memenuhi SNP.

Guru-guru yang telah mendapat pelatihan sering diminta untuk menjadi nara sumber atau fasilitator, sehingga kehadiran guru dalam kelas yang menjadi tanggung jawabnya sering terabaikan, sehingga berpengaruh terhadap mutu sekolah.

Dengan demikian di SMP Negeri 4 Sambas, mutu sekolah juga dipengaruhi oleh kualitas dan kuantitas kehadiran guru dalam proses pembelajaran di ruang kelas.

Kepala sekolah mengungkapkan persepsinya tentang mutu sekolah adalah kemampuan sekolah untuk meluluskan seluruh siswanya sesuai dengan standar yang telah ditentukan oleh pemerintah, lulusan dapat bersaing dengan lulusan sekolah lain yang sederajat untuk melanjutkan pendidikan ke sekolah selanjutnya.

Namun mutu sekolah sebagai mana di atas belum mampu direalisasikan di SMP Negeri 4 Sambas karena faktor; kualitas dan aktivitas guru, sarana prasarana, input siswa, dan kondisi lingkungan belum dikelola dengan baik sehingga mutu sekolah rendah.

Langkah-langkah yang ditempuh untuk meningkatkan mutu sekolah di SMP Negeri 4 Sambas kepala sekolah melaksanakan manajemen partisipatif.

Ada kemiripan diantara guru dalam mengungkapkan persepsi mutu sekolah yaitu bentuk pelayanan yang diberikan sekolah kepada siswa dengan ketentuan pelayanan yang diberikan dapat menjadikan anak didiknya memiliki akhlak mulia, mengamalkan ajaran agamanya dengan baik, hormat dengan guru, mematuhi peraturan yang dibuat sekolah, tingkah lakunya di sekolah maupun di masyarakat sesuai norma yang berlaku, dan hasil pelayanan yang diberikan dapat melewati standar minimal yang ditentukan oleh regulasi yang berlaku sehingga lulusan dapat melanjutkan sekolah kejenjang berikutnya. Pelayanan yang diberikan merupakan akomodasi dari semua pemikiran guru dan pegawai menjadi suatu kebijakan yang dilaksanakan oleh sekolah.

Dengan demikian kepala sekolah dan guru memberikan persepsi yang sama tentang mutu sekolah yaitu sebagai produk pelayanan yang diberikan sekolah kepada siswa dengan ketentuan hasil yang dicapai harus dapat melewati standar minimal yang ditentukan oleh regulasi yang berlaku dan lulusan dapat melanjutkan sekolah kejenjang berikutnya.

Karena mutu sekolah sangat dipengaruhi oleh kualitas dan kuantitas kehadiran guru dalam proses pembelajaran di ruang kelas, maka disarankan: 
a. Kepada pihak yang membuat kebijakan terkait pengembangan guru melalui pelatihan, penataran, MGMP, Workshop atau seminar agar membuat jadual pelaksanaan kegiatan tidak mengabaikan hak siswa untuk menerima pembelajaran dari guru yang dilibatkan dalam kegiatan tersebut.

b. Kepada kepala sekolah agar manajemen partisipatif yang telah diprogramkan lebih diintensifkan terutama menjalin hubungan harmonis dengan orangtua siswa dengan memberdayakan bagian humas dan pengurus komite sekolah.

c. Kepada guru bahwa penurunan prestasi siswa sebaiknya jangan lebih dinilai sebagai akibat dari kemalasan mereka dalam mengikuti pembelajaran tapi sebaiknya kita mengoreksi diri apakah guru sudah tepat dalam memberikan pelayanan kepada siswa. Intensitas kehadiran guru di kelas baik kualitas maupun kuntitasnya dalam proses pembelajaran perlu di optimalkan. Kerja sama itu perlu, tapi komitmen dan konsitensi terhadap tugas yang diamanahkan itu lebih perlu.

d. Perlu penelitian khusus mengenai keterkaitan antara bantuan dana dengan perubahan sistem penentuan penilian kelulusan terhadap kenaikan kelulusan di SMP Negeri 4 Sambas tahun pelajaran 2010/2011

\section{Daftar Pustaka}

Burhan Bungin (Ed). 2008. Analisis Data Penelitian Kualitatif.Pemahaman Filosofis dan Metodologis ke Arah Penguasaan Model Aplikasi. Jakarta: Rajawali Press.

Creech,Bill.1996. Lima Pilar TQM. Penerjemah. Sindoro A. Jakarta: Binarupa Aksara.

S Eko Widodo.2011. Manajemen Mutu Pendidikan: Untuk Guru dan Kepala Sekolah. Jakarta: PT. Ardadizya Jaya.

Abdul Hadis \& B.Nurhayati. 2010. Manajemen Mutu Pendidikan. Bandung: CV Alvabeta.

Ali Idrus. 2009. Manajemen Pendidikan Global: Visi, Aksi \& Adaptasi. Jakarta: Gaung Persada Press.

Engkos Kosasih. 2010. Implementasi manajemen Strategis. Di Tingkat Satuan Pendidikan Menengah. Bandung: PT Setia Purna invest.

Lexy,J. Moleong. 2011. Metodologi Penelitian kualitatif. Edisi Revisi. Bandung: PT Remaja Rosdakarya. 
E.Mulyasa. 2009. Standar Kompetensi dan Sertifikasi Guru. Bandung: PT Remaja Rosdakarya.

Mulyono. 2008. Manajemen Administrasi \& Organisasi Pendidikan. Yogjakarta: Ar-Ruzz Media.

Robbins,Stephen P. \& Judge,Timothy A. 2008. Perilaku Organisasi. Buku I. Edisi 12 : Jakarta, Salemba Empat.

Robbins,Stephen P. 1996. Prinsip-prinsip Perilaku Organisasi; Konsesp, Kontroversi, Aplikasi. Jakarta: Prenhallindo.

Sallis.Edward. 2011. Total Quality management in Education. Mutu Manajemen Pendidikan. Alih Bahasa. Riadi.A.A \& Fahrurrozi. Jogjakarta: IRCiSoD.

Herkulanus Sindju Bahari.2000. Formulasi dan Impelementasi Strategi Pendidikan Pemberdayaan Ekonomi Pedesaan Kalimantan Barat. Studi Kasus Pada YKSPK Pontianak. Tesis. Tidak diterbitkan. Malang: PPS UNM.

N,S Sukmadinata. 2010. Metode Penelitian Pendidikan. Bandung: PT.Remaja Rosdakarya.

N.S Sukmadinata..dkk. 2010. Pengendalian Mutu Pendidikan Sekolah menengah; Konsep, Prinsip, dan Instrumen. Bandung: PT Refika Aditama. 